ISSN 1392-3196 / e-ISSN 2335-8947

Zemdirbyste-Agriculture, vol. 105, No. 2 (2018), p. 159-164

DOI 10.13080/z-a.2018.105.020

\title{
The effect of silicon and boron foliar application on the quality and shelf life of cherry tomatoes
}

\author{
Mohammad Zahirul ISLAM, Mahmuda Akter MELE, Ki-Young CHOI, Ho-Min KANG \\ Kangwon National University \\ Chuncheon 24341, Republic of Korea \\ E-mail: hominkang@kangwon.ac.kr
}

\begin{abstract}
Silicon ( $\mathrm{Si}$ ) alone or $\mathrm{Si}+$ boron (B) foliar sprays at the maturity stage of light red of the cherry tomato cultivar 'Unicorn' were examined to determine the effect on the quality and shelf life. The foliar applications that were utilized in this study were: $20 \mathrm{mM} \mathrm{Si}$ alone from silicon dioxide $\left(\mathrm{SiO}_{2}\right), 20 \mathrm{mM}$ Si from $\mathrm{SiO}_{2}$ with $4.85 \mathrm{mM} \mathrm{B}$ from boric acid $\left(\mathrm{H}_{3} \mathrm{BO}_{3}\right)$ and distilled water as a control substance. The $\mathrm{Si}+\mathrm{B}$ treatment resulted in the lowest respiration and ethylene production as recorded. The $\mathrm{Si}+\mathrm{B}$ treated tomato fruits attained and retained the highest firmness as noted. Compared with the control, the $\mathrm{Si}+\mathrm{B}$ treated fruits had less-soluble solids, higher titratable acidity, higher vitamin $\mathrm{C}$ content, and longer shelf life. The $\mathrm{Si}+\mathrm{B}$ treated fruits and leaves had the highest $\mathrm{Si}$ and $\mathrm{B}$ content uptake. Therefore, $\mathrm{Si}+\mathrm{B}$ foliar sprays increased and retained cherry tomato firmness, maintained soluble solids, maintained titratable acidity, increased the vitamin $\mathrm{C}$ content, prolonged shelf life, increased cellwall compactness, and increased $\mathrm{Si}$ and $\mathrm{B}$ accumulation as noted in the study.
\end{abstract}

Key words: firmness, respiration, scanning electron microscopy, Solanum lycopersicum.

\section{Introduction}

Silicon ( $\mathrm{Si}$ ) is a "functional" plant nutrient, and its deficiency in crops has been recognized since the 1970s (Laing et al., 2006). Soluble Si is diffused in the form of mono silicic acid, $\mathrm{Si}(\mathrm{OH})_{4}$ by the plant roots and it provides effective defences for the plant to counter the susceptibility to acquire diseases (Cote-Beaulieu et al., 2009). The Si may change the antagonistic activity of huge amounts of boron (B) (Kaya et al., 2011). The content of polyphenol oxidase and ascorbate peroxidase increased in Si treated melon (Conceicao et al., 2014). The $\mathrm{Si}$ induced resistance mechanisms to biotic and abiotic stresses without hampering growth and yield of the plants treated (Liang et al., 2015). Studies show that the firmness, water status, metabolic and physiological activities were noted as improved in the $\mathrm{Si}$ treated cucumber fruit (Ouzounidou et al., 2016).

Boron deficiency in agriculture is a widespread problem that reduces yield and fruit quality of affected fruit species (Barker, Pilbeam, 2007). The variation of fruit produce quality and yield depends on the produce variety, growing environment, and nutrient solution supplied and applied to the produce as it grows (Ercisli, Orhan, 2007). Studies show that boron can influence the cell wall and plasma membrane cell wall interface, metabolism, reproductive growth and development, and root elongation and shoot growth of a growing plant structure (Marschner, 2012). It is known that boron treatment can augment and enhance the quality of tomato and cucumber plants during growth stages (Ekinci et al., 2015).

Firmness is a substantial determinant for postharvest quality, because it extends the shelf life by modifying compactness or thickness of the tomato fruit cell-wall. Silicon or $\mathrm{Si}+\mathrm{B}$ have the ability once applied to modify this result in the tomato fruit structure. In the current experiment, the reaction and consequence of $\mathrm{Si}$ alone or $\mathrm{Si}+\mathrm{B}$ foliar sprays was examined, and the result helped to ascertain the quality and shelf life of cherry tomatoes.

\section{Materials and methods}

Plant growing conditions and treatments. The cherry tomatoes (Solanum lycopersicum, cultivar 'Unicorn') were grown and cultivated using a nutrient film technique (NFT) system during the summer, while situated in the growing environment at a plastic house in Gangwon Province, Korea in 2014. The maturity-stage of light red was utilized to perform this experiment. The package size of the storage tomato was $34 \times 24 \times 13 \mathrm{~cm}$. The storage temperatures for the tomatoes were 5 and $11^{\circ} \mathrm{C}$ with $85 \%$ relative humidity. A supplied nutrient for nourishing the tomatoes during the growth stages was based on the Japanese horticultural experiment station (Sato et al., 2006). The maintained electrical conductivity (EC) was $2.2 \mathrm{dS} \mathrm{m}^{-1}$, and the potential of hydrogen $(\mathrm{pH})$

Please use the following format when citing the article:

Islam M. Z., Mele M. A., ChoiK.-Y. , Kang H.-M. 2018. The effect of silicon and boron foliar application on the quality and shelf life of cherry tomatoes. Zemdirbyste-Agriculture, 105 (2): 159-164 DOI 10.13080/z-a.2018.105.020 
was 5.8-6.2 in the supplied nutrient solution to the plant specimens. The foliar spray treatments were $20 \mathrm{mM} \mathrm{Si}$ alone from silicon dioxide $\left(\mathrm{SiO}_{2}\right), 20 \mathrm{mM}$ Si from $\mathrm{SiO}_{2}$ with $4.85 \mathrm{mM} \mathrm{B}$ from boric acid $\left(\mathrm{H}_{3} \mathrm{BO}_{3}\right)$ and distilled water as a control. A $50 \mathrm{ml}$ solution per plant was sprayed on the three trusses bearded tomato plants in every week of the experiment, and the total duration of the study was five weeks. The plants were subsequently deadheaded when these bearded seven trusses died back in each plant.

Fruit physiology parameters. The respiration and ethylene were quantified by a gas analyser PBIDansensor CheckMate 9900 (Dansensor A/S, Denmark) and a gas chromatograph GC-2010 (Shimadzu, Japan), respectively (Mele et al., 2017).

Fruit physico-chemical quality parameters. The firmness and the soluble solids were ascertained by a penetrometer DFT-01 (TR Snc, Italy) and a refractometer (Atago USA Inc.), respectively. A food and beverage tester DL 22 (Mettler Toledo Ltd., Korea) was used to measure the titratable acidity. Vitamin $\mathrm{C}$ was analyzed according to the method of Mele et al. (2017) using a Waters high-performance liquid chromatography (Waters Associates, USA) which equipped with $\mathrm{C}_{18}$ column $(4.6 \mathrm{~cm} \times 250 \mathrm{~mm}, 5 \mu \mathrm{m})$ (Agilent, USA) at $265 \mathrm{~nm}$. The tomato fresh weight loss for each tomato plant was estimated by deducting the present weight from the earlier weights and converted as percent of weight loss. The visual quality was measured on a 5-point scale: 5 excellent, 4 - very good, 3 - good, marketable, 2 - bad and 1 - waste, of the $y$ axis in Figure 2 during storage by five panel members (Mele et al., 2017).

Silicon (Si) and boron (B) content analysis. The $\mathrm{Si}$ and $\mathrm{B}$ contents as applied to the plants were measured according to Simsek and Aykut (2007) with the help of inductively coupled plasma (ICP) - atomic emission spectroscopy (AES) Integra XL Dual (GBC Scientific Equipment Pty Ltd., Australia) succeeding astringent assimilation, and the result was recorded like a concentration ( $\mathrm{mg} \mathrm{kg}^{-1}$ dry weight).

Scanning electron microscopy (SEM). The Si alone or combined with B treated tomatoes SEM was analyzed by a Supra 55VP (Carl Zeiss, Germany) at a hastening of $3 \mathrm{KV}$ voltage. The top second and third layers of digital pictures were used to calculate the compactness or thickness of cell-wall by software $\mathrm{NIH}$ Image (http://rsb.info.nih.gov/nih-image/).

Statistical analysis. Data was analyzed by the utilization of the statistics software SPSS V.16 (SPSS Inc., USA). The Duncan's multiple range test of the one-way analysis of variance ( $A N O V A)$ was used to analyze the mean significant differences of all tomato fruits utilized and monitored in the study.

\section{Results and discussion}

Fruit physiology parameters. The study noted that the tomato fruit quality begins to deteriorate immediately after harvest due to a high respiration rate. A reduced level of respiration can help maintain the fruit quality and increase the shelf life of the tomato. The $\mathrm{Si}+\mathrm{B}$ treated fruits showed a significantly $(p \leq 0.05)$ reduced respiration rate than the control fruits of light red maturity at harvest time $\left(20^{\circ} \mathrm{C}\right)$. Moreover, $\mathrm{Si}+\mathrm{B}$ treated fruits showed lower respiration rate at both storage temperatures of red maturity-stage cherry tomato than control fruits on the last storage day. These findings are in agreement with the results reported by Vunnam et al. (2014) that noted a respiration rate was satisfactory maintained by the maturity, growing atmosphere and tomato fruits surrounding the gas condition. At harvest time and during storage, the respiration of the tomato was suppressed by the $\mathrm{Si}+\mathrm{B}$ treatment and this might have happened as a result of the subsequent cell-wall thickness of the study tomato fruits. The Kaluwa et al. (2010) study revealed that $\mathrm{Si}$ suppressed the respiration in similarity reviewed growth of avocadoes. It was noted that the use of boron suppressed the respiration of pears by improving their membrane integrity (Xuan et al., 2005). Among the treatments, $\mathrm{Si}+\mathrm{B}$ showed the lowest respiration rate (Table 1); thus the $\mathrm{Si}+\mathrm{B}$ treated tomato fruits had the longest shelf life.

Ethylene helps to ripen tomato fruits, and a decreased level of ethylene may be desirable to reduce the maturing procedure and increase the shelf life. At harvest time $\left(20^{\circ} \mathrm{C}\right)$, the $5^{\circ} \mathrm{C}$ and $11^{\circ} \mathrm{C}$ stored cherry tomatoes showed a decreased ethylene production rate as compared to the control (Table 1). Moreover, the $\mathrm{Si}+\mathrm{B}$ treated tomato fruits in $11^{\circ} \mathrm{C}$ storage showed a lower ethylene production rate than the control fruits. The $\mathrm{Si}+\mathrm{B}$ foliar sprays may decrease the ethylene production of cherry tomatoes by maintaining respiration. The silicon application decreased the ethylene production rate in avocadoes (Kaluwa et al., 2010). In pears, B decreased the ethylene production rate by maintaining the membrane structure and its integrity (Xuan et al., 2005). Although harvest-time colour $\mathrm{a}^{*} / \mathrm{b}^{*}$ value was not significantly different of tomato fruits as we selected the same maturity stage (data not shown), but they significantly differed in ethylene production rate. $\mathrm{The} \mathrm{Si}+\mathrm{B}$ treated tomato fruits had the lowest ethylene production; it may be beneficial in prolonging the shelf life of cherry tomatoes.

Fruit quality parameters. Firmness is a fundamental feature of the cultivated cherry tomato, and it reduces gradually over time especially in storage

Table 1. The respiration and ethylene production rate at harvest time $\left(20^{\circ} \mathrm{C}\right), 5^{\circ} \mathrm{C}\left(25^{\text {th }}\right.$ storage day) and $11^{\circ} \mathrm{C}$ $\left(10^{\text {th }}\right.$ storage day) of $\mathrm{Si}$ alone and $\mathrm{Si}+\mathrm{B}$ foliar spraying treatment of cherry tomato

\begin{tabular}{|c|c|c|c|c|c|c|}
\hline \multirow[t]{2}{*}{ Treatment } & \multicolumn{3}{|c|}{$\begin{array}{c}\text { Respiration } \\
\mathrm{CO}_{2} \mathrm{ml} \mathrm{kg}^{-1} \mathrm{hr}^{-1}\end{array}$} & \multicolumn{3}{|c|}{$\begin{array}{l}\text { Ethylene production rate } \\
\qquad \mu \mathrm{L} \mathrm{kg}^{-1} \mathrm{hr}^{-1}\end{array}$} \\
\hline & harvest & $5^{\circ} \mathrm{C}$ & $11^{\circ} \mathrm{C}$ & harvest & $5^{\circ} \mathrm{C}$ & $11^{\circ} \mathrm{C}$ \\
\hline Control & $2.58 \mathrm{a}$ & $0.75 \mathrm{a}$ & $0.91 \mathrm{a}$ & $4.17 \mathrm{a}$ & $3.27 \mathrm{a}$ & $2.05 \mathrm{a}$ \\
\hline $\mathrm{Si}$ & $2.14 \mathrm{ab}$ & $0.65 \mathrm{a}$ & $0.84 \mathrm{ab}$ & $3.41 \mathrm{ab}$ & $2.63 \mathrm{ab}$ & $1.98 \mathrm{a}$ \\
\hline $\mathrm{Si}+\mathrm{B}$ & $2.02 \mathrm{~b}$ & $0.41 \mathrm{~b}$ & $0.75 \mathrm{~b}$ & $3.17 \mathrm{~b}$ & $2.51 \mathrm{~b}$ & $1.46 \mathrm{~b}$ \\
\hline$P$ values & $*$ & $* * *$ & $*$ & $*$ & $*$ & $*$ \\
\hline
\end{tabular}

Note. The Duncan's multiple range test was used for mean $(\mathrm{n}=5)$ separation of columns; * and *** - significant at $p \leq 0.05$ and 0.001 , respectively. 
facilities. The extended firmness of the cherry tomato fruit is desirable for long-time storage and possible logistical transportation. The firmness increased by $\mathrm{Si}$ $+\mathrm{B}$ treated tomato fruits at harvest time was significant and the tomato fruits retained their firmness with this application even after storage (Table 2). The $\mathrm{Si}+\mathrm{B}$ foliar sprays influenced firmness, because the minerals may cross-link the pectin molecules in plant cell-walls and the metal binding's cell-wall structure stabilize by the pectin web in the case of this study. The Si treatment expanded tomato firmness (Weerahewa, David, 2015) and B-treated pear fruits have been shown to become firmer (Khalaj et al., 2017) which is definite beneficial growing factor for producers of these fruit products. Moreover, the $\mathrm{Si}$ $+\mathrm{B}$ treated fruit showed the highest firmness at harvest time $\left(20^{\circ} \mathrm{C}\right)$, and it was retained after storage due to decreased respiration and ethylene production. The Xuan et al. (2005) study reported that the application and B treatment delayed the damage of fruit tissue and reduced the disorder in similarly situated cultivated fruits during harvest times.

Table 2. The cherry tomato firmness, soluble solids, titratable acidity and vitamin $\mathrm{C}$ at harvest time $\left(20^{\circ} \mathrm{C}\right), 5^{\circ} \mathrm{C}$ $\left(25^{\text {th }}\right.$ storage day $)$ and $11^{\circ} \mathrm{C}\left(10^{\text {th }}\right.$ storage day $)$ of $\mathrm{Si}$ alone and $\mathrm{Si}+\mathrm{B}$ foliar spraying treatment

\begin{tabular}{|c|c|c|c|c|c|c|c|c|c|c|c|c|}
\hline \multirow[t]{2}{*}{ Treatment } & \multicolumn{3}{|c|}{$\begin{array}{c}\text { Firmness } \\
\mathrm{N} \\
\end{array}$} & \multicolumn{3}{|c|}{$\begin{array}{l}\text { Soluble solids } \\
{ }^{\circ} \text { Brix } \\
\end{array}$} & \multicolumn{3}{|c|}{$\begin{array}{c}\text { Titratable acidity, } \\
\% \text { citric acid }\end{array}$} & \multicolumn{3}{|c|}{$\begin{array}{c}\text { Vitamin C } \\
\mathrm{mg} 100 \mathrm{~g}^{-1} \mathrm{FW}\end{array}$} \\
\hline & harvest & $5^{\circ} \mathrm{C}$ & $11^{\circ} \mathrm{C}$ & harvest & $5^{\circ} \mathrm{C}$ & $11^{\circ} \mathrm{C}$ & harvest & $5^{\circ} \mathrm{C}$ & $11^{\circ} \mathrm{C}$ & harvest & $5^{\circ} \mathrm{C}$ & $11^{\circ} \mathrm{C}$ \\
\hline Control & $18.18 \mathrm{~b}$ & $9.01 \mathrm{~b}$ & $11.70 \mathrm{~b}$ & $7.61 \mathrm{a}$ & $7.63 \mathrm{a}$ & $7.81 \mathrm{a}$ & $0.58 \mathrm{~b}$ & $0.53 \mathrm{~b}$ & $0.51 \mathrm{~b}$ & $12.94 \mathrm{~b}$ & $10.24 \mathrm{~b}$ & $10.04 \mathrm{~b}$ \\
\hline $\mathrm{Si}$ & $20.73 a b$ & $10.64 \mathrm{ab}$ & $14.02 \mathrm{ab}$ & $7.27 \mathrm{a}$ & $7.50 \mathrm{ab}$ & $7.46 \mathrm{ab}$ & $0.69 \mathrm{ab}$ & $0.55 \mathrm{~b}$ & $0.55 \mathrm{ab}$ & $15.07 \mathrm{ab}$ & $13.01 \mathrm{ab}$ & $11.71 \mathrm{ab}$ \\
\hline $\mathrm{Si}+\mathrm{B}$ & $22.78 \mathrm{a}$ & $13.96 \mathrm{a}$ & $16.57 \mathrm{a}$ & $6.66 \mathrm{~b}$ & $7.17 \mathrm{~b}$ & $7.21 \mathrm{~b}$ & $0.75 \mathrm{a}$ & $0.70 \mathrm{a}$ & $0.65 \mathrm{a}$ & $18.19 \mathrm{a}$ & $14.02 \mathrm{a}$ & $13.06 \mathrm{a}$ \\
\hline$P$ values & $* * *$ & $*$ & $* *$ & $* * *$ & $*$ & $*$ & $* *$ & $*$ & $*$ & $* * *$ & $* *$ & $*$ \\
\hline
\end{tabular}

Note. FW - fresh weight; the Duncan's multiple range test was used for mean $(\mathrm{n}=10)$ separation of columns; ${ }^{*}, *^{* *}$ and ${ }^{* * *}$ significant at $p \leq 0.05,0.01$ and 0.001 , respectively.

Both at harvest time and after storage, the $\mathrm{Si}+\mathrm{B}$ treated tomato fruits showed less soluble solids compared with control (Table 2), and this might have happened as a result of slower respiration and ethylene production. As B transports sugar through the formation of borate-sugar complexes in higher plants (Marschner, 2012), there may be a case resulting in the less soluble solids in B treated fruits at harvest time. Si-treated tomatoes also had less-soluble solids as noted in the fruit growth statistics (Weerahewa, David, 2015). Additionally, it is noted that during storage, soluble solids increased perhaps due to conversion of starch to sugar (Khalaj et al., 2017).

The cherry tomato fruit treated with $\mathrm{Si}+\mathrm{B}$ had a higher titratable acidity at the harvest time and after storage compared to the control (Table 2), which could be attributed to low respiration rate, low metabolic activities to increase the shelf life. During storage, it is noted that the titratable acidity decreased in B treated pears (Khalaj et al., 2017). Consequently, fruits treated with $\mathrm{Si}+\mathrm{B}$ foliar sprays showed the highest titratable acidity among the treatments due to the smallest respiration content, including the factors of less-ethylene production, and less-soluble solids.

By the same light, $\mathrm{Si}+\mathrm{B}$ treatment showed the highest vitamin $\mathrm{C}$ at harvest time and after storage, thereby noting the control recorded the lowest vitamin $\mathrm{C}$ (Table 2). The $\mathrm{Si}+\mathrm{B}$ treatment on the tomato fruits showed the highest vitamin $\mathrm{C}$ because of lower metabolic activities. The B-treated pomegranate showed the highest vitamin $\mathrm{C}$ content (Korkmaz et al., 2016). The $\mathrm{Si}+\mathrm{B}$ foliar sprays had the greatest effect on the vitamin $\mathrm{C}$ content. Moreover, the vitamin $\mathrm{C}$ content variation also depended on the tomato cultivar (Guil-Guerrero, Rebolloso-Fuentes, 2009), Si + B treatments, temperature and maturity stages.

Fresh weight loss. Because of the fruits' moisture loss from respiration, the stored tomato fruits fresh weight loss rate increased when weighed and reviewed. The pre-harvest foliar sprays in strawberries studied did not show any differences in fresh weight loss (Singh et al., 2007), but our results for the Si alone and Si $+\mathrm{B}$ treatments were significantly different in the cherry tomatoes reviewed in this study. The $\mathrm{Si}+\mathrm{B}$ treated tomato fruits showed the lowest fresh weight loss during storage (Fig. 1). Moreover, at $5^{\circ} \mathrm{C}$, the stored tomatoes showed less fresh weight loss than at $11^{\circ} \mathrm{C}$; therefore, the $\mathrm{Si}+$ $\mathrm{B}$ treatment and $5^{\circ} \mathrm{C}$ temperature significantly reduced the fresh weight loss of cherry tomatoes by reducing the respiration.

Visual quality. Tomato fruits' market price usually depends on the visually high quality of the fruits. Therefore, good visual quality fruits are preferable to sellers, buyers and consumers in all buying markets. The $\mathrm{Si}+\mathrm{B}$ treated fruits at $5^{\circ} \mathrm{C}$ and $11^{\circ} \mathrm{C}$ storage had the best visual quality of the fruits tested in this study. The marketable, good visual tomato quality or shelf life $(\geq 3)$ was maintained for 14 days (control), 16 days (Si alone) and 19 days $(\mathrm{Si}+\mathrm{B})$ at $5^{\circ} \mathrm{C}$ based on an observation scale. Moreover, at $11^{\circ} \mathrm{C}$ storage cherry tomatoes' shelf life was 6 days (control), 8 days ( $\mathrm{Si}$ alone) and 9 days ( $\mathrm{Si}$ + B) treatment (Fig. 2). The $\mathrm{Si}+\mathrm{B}$ foliar sprays retained visual quality, improved the shelf life, and maintained the fruit freshness by suppressing respiration and reducing internal breakdown. The silicon treatment also resulted in a better visual quality than in the control as noted and reviewed in this study.

The $\mathrm{Si}$ reduced deterioration of cucumber by maintaining membrane integrity (Ouzounidou et al., 2016). B reduced the susceptibility of nectarine fruit rots caused by brown rot (Thomidis et al., 2017). These treatments retained the tomatoes' visual quality, improved their shelf life, and maintained freshness for a longer period of time. The $\mathrm{Si}+\mathrm{B}$ foliar sprays resulted in the longest shelf life of cherry tomatoes at both $5^{\circ} \mathrm{C}$ and $11^{\circ} \mathrm{C}$ by maintaining freshness. 

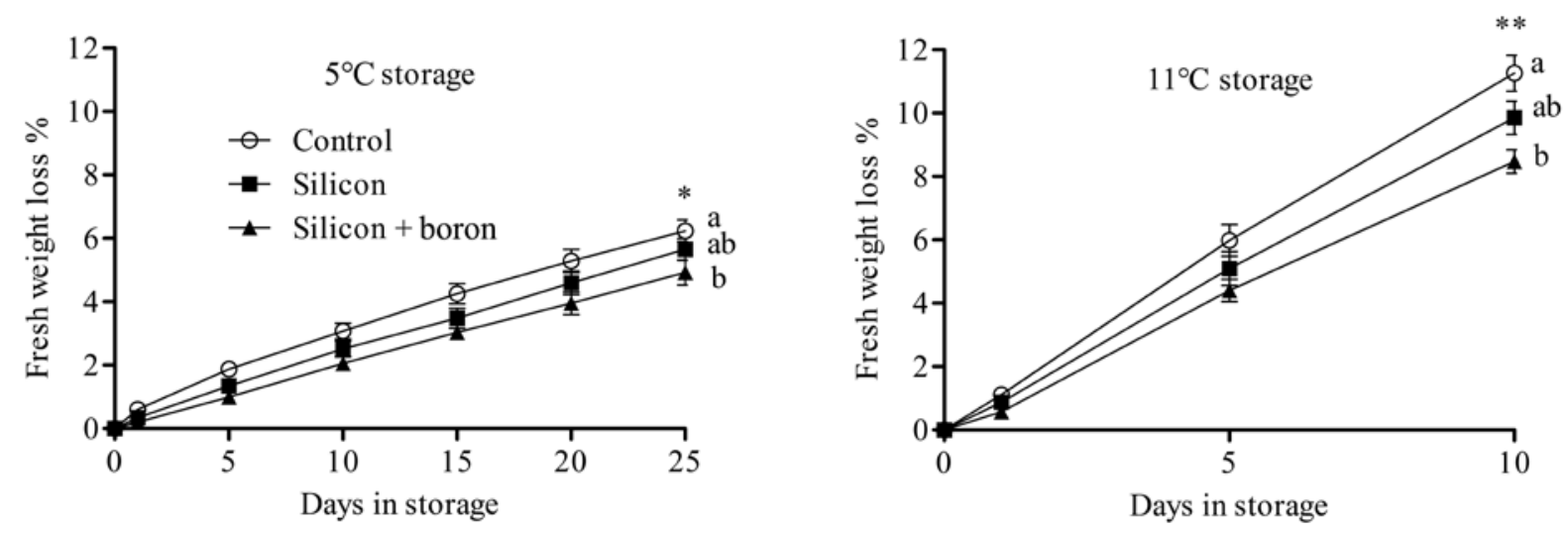

Note. Data represents the mean \pm standard error $(\mathrm{n}=10) ;{ }^{*}$ and $* *-$ significant at $p \leq 0.05$ and 0.01 , respectively, of Duncan's multiple range test.

Figure 1. The cherry tomato fresh weight loss of $\mathrm{Si}$ alone and $\mathrm{Si}+\mathrm{B}$ foliar spraying treatment
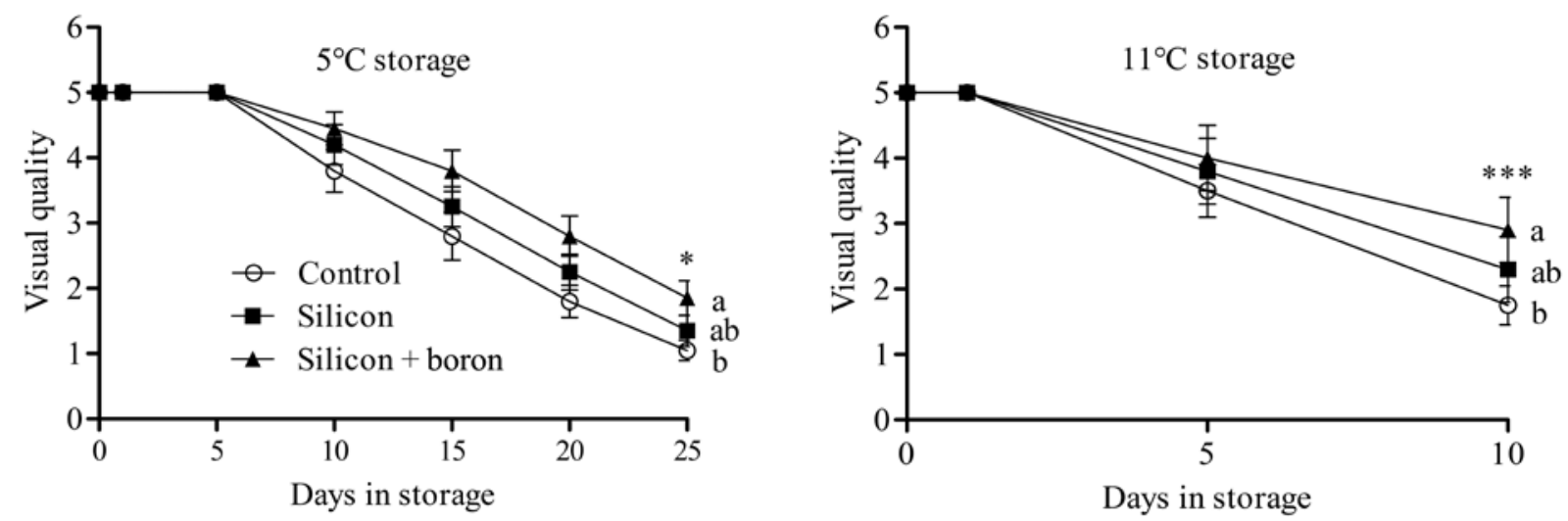

Note. The visual quality was measured on a 5-point scale (5 - excellent, 4 - very good, 3 - good, marketable, 2 - bad and 1 - waste) of the $y$ axis; data represents the mean \pm standard error $(\mathrm{n}=10) ; *$ and $* * *-$ significant at $p \leq 0.05$ and 0.001 , respectively of Duncan's multiple range test.

Figure 2. The cherry tomato visual quality of $\mathrm{Si}$ alone and $\mathrm{Si}+\mathrm{B}$ foliar spraying treatment

Scanning electron microscopy (SEM). The $\mathrm{Si}+$ $\mathrm{B}$ foliar sprays resulted in more-compact tissue compared to the control tomato fruits, because those treatments used a $\mathrm{Si}+\mathrm{B}$ composition in the cell-wall structure, thus, decreasing the intercellular spaces and increasing the compactness and firmness. The highest cell-wall thickness was found in the $\mathrm{Si}+\mathrm{B}$ treated fruits, followed by $\mathrm{Si}$ alone and the control (Fig. 3). The Si treatment resulted in more-compact tissue (Bae et al., 2010), and B improved the membrane integrity and cell-wall formation in pears (Khalaj et al., 2017). The cell walls were thicker in the treated tomatoes, indicating that the $\mathrm{Si}$ alone and $\mathrm{Si}$
+ B treatments increase the cell-wall thickness, membrane integrity and cell-wall formation and, therefore, resulted in an increase in the fruits' shelf life.

Fruit and leaf Si and $B$ content analysis. The $\mathrm{Si}+\mathrm{B}$ foliar sprays resulted in higher Si and B content compared to the control and it probably happened due to greater assimilation of $\mathrm{Si}$ and $\mathrm{B}$ in the fruits and leaves. The B treatment increased the B content in cucumbers and in tomatoes (Kaya et al., 2011; Ekinci et al., 2015). As the tomato plants accumulated higher $\mathrm{Si}$ and $\mathrm{B}$ contents, the cell-wall thickness, fruit firmness and shelf life increased (Table 3).

Table 3. The silicon (Si) and boron (B) content ( $\mathrm{mg} \mathrm{kg}^{-1}$ dry weight) in fruit and leaf of cherry tomato of Si alone and $\mathrm{Si}+\mathrm{B}$ foliar spraying treatment

\begin{tabular}{ccccc}
\hline \multirow{2}{*}{ Treatment } & \multicolumn{2}{c}{$\mathrm{Si}$} & fruit & leaf \\
\cline { 2 - 5 } & fruit & leaf & $5.71 \mathrm{~b}$ & $70.52 \mathrm{~b}$ \\
Control & $267.09 \mathrm{~b}$ & $332.90 \mathrm{~b}$ & $6.21 \mathrm{ab}$ & $72.94 \mathrm{~b}$ \\
$\mathrm{Si}$ & $284.55 \mathrm{a}$ & $339.52 \mathrm{ab}$ & $7.11 \mathrm{a}$ & $97.53 \mathrm{a}$ \\
$\mathrm{Si}+\mathrm{B}$ & $289.84 \mathrm{a}$ & $347.74 \mathrm{a}$ & $* * *$ & $* *$ \\
$P$ values & $*$ & $*$ & $*$
\end{tabular}

Note. The Duncan's multiple range test was used for mean $(\mathrm{n}=5)$ separation of columns; $*$, ${ }^{*}$ and $* * *-$ significant at $p \leq 0.05$, 0.01 and 0.001 , respectively. 

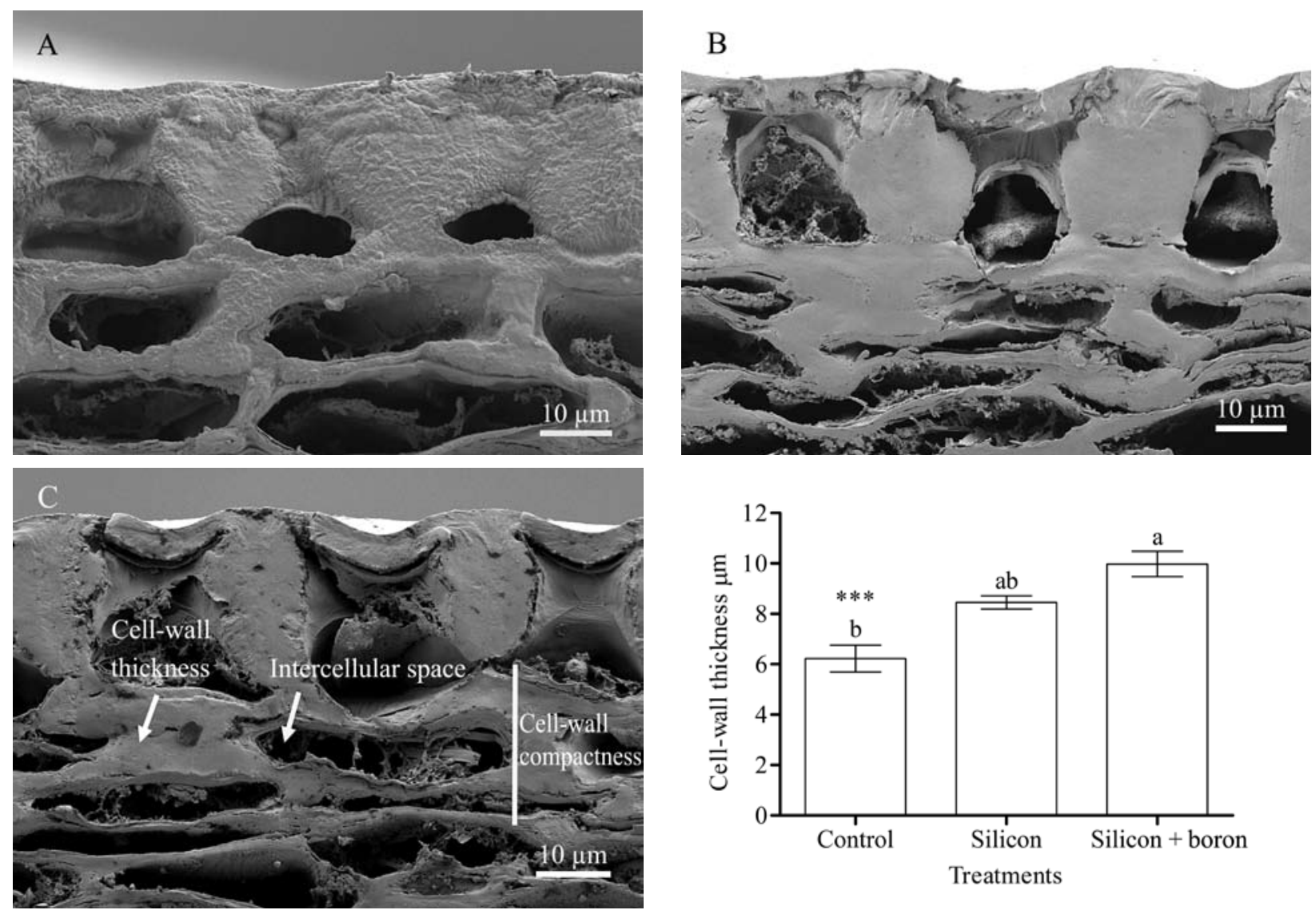

Note. Data represents the mean \pm standard error $(\mathrm{n}=10)$ of cell-wall thickness in the graph, $* * *-$ significant at $p \leq 0.001$ of Duncan's multiple range test; the cell-wall thickness (A - control, B - silicon, C - silicon + boron) of the top second and third layer was calculated by using software NIH image of $\mathrm{Si}$ alone and $\mathrm{Si}+\mathrm{B}$ foliar spraying treatment.

Figure 3. The cherry tomato cell wall in the scanning electron microscopy (SEM) analysis $(\mathrm{EHT}=3.00 \mathrm{kV}$, Mag $=$ $3.00 \mathrm{KX}$ and $10 \mu \mathrm{m}$ scale)

\section{Conclusion}

The effects of foliar spraying of silicon (Si) or $\mathrm{Si}+$ boron (B) were investigated to confirm the quality and shelf life of cherry tomatoes. The application of $\mathrm{Si}$ $+\mathrm{B}$ treatment showed lower respiration, less ethylene production, increased firmness, increased cell-wall compactness, and accumulated maximum $\mathrm{B}$ and $\mathrm{Si}$ content compared with Si treatment or control tomato fruits. The application of $\mathrm{Si}+\mathrm{B}$ treatment also had a prolonged shelf life. This treatment could result in grower, seller, buyer, and/or consumer increased satisfaction and overall appreciation with cherry tomato fruit quality and economic value in produce based markets in the region.

\section{Acknowledgements}

This research was supported by Export Promotion Technology Development Program (3140273), IPET (Korea Institute of Planning and Evaluation for Technology in Food, Agriculture, Forestry and Fisheries), Ministry of Agriculture, Food and Rural Affairs, Republic of Korea.

Received 13052017

Accepted 19092017

\section{References}

1. Bae M. J., Park Y. G., Jeong B. R. 2010. Effects of a silicate fertilizer supplemented to the medium on rooting and subsequent growth of potted plants. Horticulture Environment Biotechnology, 51 (5): 355-359.

2. Barker A. V., Pilbeam D. J. (eds.). 2007. Handbook of plant nutrition, $632 \mathrm{p}$.

3. Conceicao C. S., Felix K. C. S., Mariano R. L. R., Medeiros E. V., Souza E. B. 2014. Combined effect of yeast and silicon on the control of bacterial fruit blotch in melon. Scientia Horticulturae, 174: 164-170. https://doi.org/10.1016/j.scienta.2014.05.027

4. Cote-Beaulieu C., Chain F., Menzies J. G., Kinrade S. D., Belanger R. R. 2009. Absorption of aqueous inorganic and organic silicon compounds by wheat and their effect on growth and powdery mildew control. Environmental and Experimental Botany, 65: 155-161.

https://doi.org/10.1016/j.envexpbot.2008.09.003

5. Ekinci M., Esring A., Dursun A., Yildirim E., Turan M., Karaman M. R., Arjumend T. 2015. Growth, yield, and calcium and boron uptake of tomato (Lycopersicon esculentum L.) and cucumber (Cucumis sativus L.) as affected by calcium and boron humate application in greenhouse conditions. Turkish Journal Agriculture and Forestry, 39: 613-632.

https://doi.org/10.3906/tar-1406-59

6. Ercisli S., Orhan E. 2007. Chemical composition of white (Morus alba), red (Morus rubra) and black (Morus nigra) mulberry fruits. Food Chemistry, 103 (4): 1380-1384. https://doi.org/10.1016/j.foodchem.2006.10.054 
7. Guil-Guerrero J. L., Rebolloso-Fuentes M. M. 2009. Nutrient composition and antioxidant activity of eight tomato (Lycopersicon esculentum) varieties. Journal of Food Composition and Analysis, 22 (2): 123-129. https://doi.org/10.1016/j.jfca.2008.10.012

8. Laing M. D., Gatarayiha M., Adandonon A. 2006. Silicon use for pest control in agriculture: a review. Proceedings of the South African Sugar Technologist's Association, 80: 278-286.

9. Liang Y., Nikolic M., Belanger R., Gong H., Song A. 2015. Silicon in agriculture: from theory to practice. Springer, Amsterdam. The Netherlands, $325 \mathrm{p}$. https://doi.org/10.1007/978-94-017-9978-2

10. Kaya C., Tuna A. L., Guneri M., Ashraf M. 2011. Mitigation effects of silicon on tomato plants bearing fruit grown at high boron levels. Journal of Plant Nutrition, 34 (13): 1985-1994. https://doi.org/10.1080/01904167.2011.610485

11. Kaluwa K., Bertling I., Bower J. P., Tesfay S. Z. 2010. Silicon application effects on 'Hass' avocado fruit physiology. South African Avocado Growers' Association Yearbook, 33: 44-47.

12. Khalaj K., Ahmadi N., Souri M. K. 2017. Improvement of postharvest quality of Asian pear fruits by foliar application of boron and calcium. Horticulturae 3 (15): 1-8. https://doi.org/10.3390/horticulturae3010015

13. Korkmaz N., Askin M. A., Ercisli S., Okatan V. 2016. Boric acid and gibberellic acid affects yield and quality of pomegranate (Punica granatum L.). Acta Scientiarum Polonorum Hortorum Cultus, 15 (3): 105-112.

14. Marschner H. 2012. Mineral nutrition of higher plants. London, UK, p. 347-364.

15. Mele M. A., Islam M. Z., Baek J. P., Kang H. M. 2017. Quality, storability, and essential oil content of Ligularia fischeri during modified atmosphere packaging storage. Journal of Food Science and Technology, 54 (3): 743-750. https://doi.org/10.1007/s13197-017-2514-y

16. Ouzounidou G., Giannakoula A., Ilias I., Zamanidis P. 2016. Alleviation of drought and salinity stresses on growth, physiology, biochemistry and quality of two
Cucumis sativus L. by Si application. Brazilian Journal of Botany, 39 (2): 531-539. https://doi.org/10.1007/s40415-016-0274-y

17. Sato S., Sakaguchi S., Furukawa H., Ikeda H. 2006. Effects of $\mathrm{NaCl}$ application to hydroponic nutrient solution on fruit characteristics of tomato (Lycopersicon esculentum Mill.). Scientia Horticulturae, 109: 248-253. https://doi.org/10.1016/j.scienta.2006.05.003

18. Simsek A., Aykut O. 2007. Evaluation of the microelement profile of Turkish hazelnut (Corylus auellana L.) varieties for human nutrition and health. International Journal of Food Sciences and Nutrition, 58: 677-688. https://doi.org/10.1080/09637480701403202

19. Singh R., Sharma R. R., Tyagi S. K. 2007. Pre-harvest foliar application of calcium and boron influences physiological disorders, fruit yield and quality of strawberry (Fragaria $\times$ ananassa Duch.). Scientia Horticulturae, 112: 215-220. https://doi.org/10.1016/j.scienta.2006.12.019

20. Thomidis T., Karagiannidis N., Stefanou S. 2017. Influence of boron applications on preharvest and postharvest nectarine fruit rot caused by brown rot. Australasian Plant Pathology, 46 (2): 177-181.

https://doi.org/10.1007/s13313-017-0474-3

21. Vunnam R., Hussain A., Nair G., Bandla R., Gariepy Y., Donnelly D. J., Kubow S., Raghavan G. S. V. 2014. Physicochemical changes in tomato with modified atmosphere storage and UV treatment. Journal of Food Science and Technology, 51 (9): 2106-2112. https://doi.org/10.1007/s13197-012-0690-3

22. Weerahewa D., David D. 2015. Effect of silicon and potassium on tomato anthracnose and on the postharvest quality of tomato fruit (Lycopersicon esculentum Mill.). Journal of National Science Foundation Sri Lanka, 43 (3): 273-280. https://doi.org/10.4038/jnsfsr.v43i3.7959

23. Xuan H., Streif J., Saquet A., Romheld V., Bangerth F. 2005. Application of boron with calcium affects respiration and ATP/ADP ratio in 'Conference' pears during controlled atmosphere storage. Journal of Horticultural Science and Biotechnology, 80 (5): 633-637.

https://doi.org/10.1080/14620316.2005.11511990

ISSN 1392-3196 / e-ISSN 2335-8947

Zemdirbyste-Agriculture, vol. 105, No. 2 (2018), p. 159-164

DOI 10.13080/z-a.2018.105.020

\title{
Vyšninių pomidorų purškimo per lapus siliciu ir boru įtaka vaisių prekinei kokybei
}

\author{
M. Z. Islam, M. A. Mele, K.-Y. Choi, H.-M. Kang \\ Kangvono nacionalinis universitetas, Korejos Respublika
}

\section{Santrauka}

Tyrimo metu siekta nustatyti silicio ( $\mathrm{Si}$ ) arba $\mathrm{Si}+$ boro $(\mathrm{B})$ mišinių, kuriais per lapus buvo purkšti šviesiai raudonos brandos veislès 'Unicorn' vyšniniai pomidorai, įtaką vaisių kokybei ir tinkamumo vartoti laikotarpiui. Per lapus

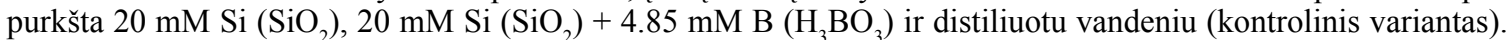
Nupurškus Si + B mišiniu buvo nustatyta mažiausia respiracija ir etileno sintezè. Didžiausią kietumą pasieke ir išlaikè pomidoru vaisiai, nupurkšti $\mathrm{Si}+\mathrm{B}$ mišiniu. Palyginus su kontroliniu variantu, $\mathrm{Si}+\mathrm{B}$ mišiniu nupurkšti vaisiai turèjo mažiau tirpių kietujų dalelių, didesnị titruojamąji rūgštumą, didesnị kiekị vitamino $\mathrm{C}$ ir ilgesnị vartojimo laika. $\mathrm{Si}+\mathrm{B}$ mišiniu nupurkšti vaisiai ir lapai ịsisavino didžiausią kieki Si bei $\mathrm{B}$. Dèl to $\mathrm{Si}+\mathrm{B}$ mišinio purškimas per lapus padidino ir išlaikè vyšniniu pomidoru kietumą, tirpių kietuju medžiagų kiekí, titruojamajj rūgštumą, padidino vitamino C kiekį, pailgino vartojimo laiką, padidino ląstelès sienelès kompaktiškumą ir Si bei B kaupimąsi.

Reikšminiai žodžiai: kietumas, kvėpavimas, skenuojanti elektroninė mikroskopija, Solanum lycopersicum. 